Article

\title{
Studies on Serum Total Cholesterol, in Second and Third Trimester of Pregnancy
}

\author{
Husain $\mathrm{F}^{1}$, Latif SA ${ }^{2}$, Uddin $\mathrm{MM}^{3}$
}

Study was carried out in the department of physiology, Mymensingh Medical College, Mymensingh, Bangladesh during the period of July 2006 to June 2007 to investigate the effect of pregnancy on serum total cholesterol. The serum concentrations of total cholesterol was measured in 100 cases of $2^{\text {nd }}$ and $3^{\text {rd }}$ trimester of pregnancy and in a control group of 100 cases of non pregnant women which was matched on reproductive age. Data were analyzed by computer with SPSS program using unpaired student ' $t$ ' test. The results showed that the pregnant women had significantly higher concentrations of serum total cholesterol. Higher concentration of total cholesterol was more common in pregnant than control and reaching maximum at $3^{\text {rd }}$ trimester of pregnancy.

This may be a purely physiological response to pregnancy or it may be indication of pathology in some women. These results deserve a follow up study to investigate whether the hypercholesterolemia persists after parturition.

Key Words: Total cholesterol, pregnancy, parturition, hypercholesterolemia

J Bangladesh Soc Physiol. 2006 Dec;(1):1-4. For author affiliations, see end of text.

\section{Introduction}

$\mathbf{P}$ regnancy is a new sequence of events after fertilization of ovum ${ }^{1}$. The physiology of pregnancy is concerned primarily with the nutrition of growing fetus and with the maternal adaptation needed for this purpose. Lipid changes during pregnancy are a result of phyhysiological adaptation to the state pregnancy. There are increases in the blood concentration of cholesterol, triglyceride and phospholipids ${ }^{2}$.

Toward the end of pregnancy, the daily production of placental estrogen and progesterone increases about 30 and 10 times the mother's normal level of production respectively ${ }^{1}$. Estrogen generally tends to increase serum triglyceride and HDL-cholesterol and decreases serum LDL-cholesterol and total cholesterol. Whereas progesterone tends to produce, the opposite effects and thus counteract the action of the estrogen ${ }^{3}$. Hormonal change during pregnancy induces changes in composition of lipid, making it more atherogenic as pregnancy progress ${ }^{4}$. Hyperlipidaemia is defined as excess concentration of cholesterol or triglyceride or both in plasma ${ }^{5}$. Increased serum lipid and lipoprotein concentrations are recognized risk factor for atheromatous cardiovascular diseases ${ }^{6}$. Effective control the blood lipid level reduces cardiovascular morbidity and mortality both in patient with established CHD and those at risk of developing $\mathrm{CHD}^{7}$. Although pregnancy has been shown to increase serum total cholesterol and triglyceride, its effect on apolipoprotein and lipoprotein has not been adequately characterized .More over the prevalence, extent of these alteration, the duration of changing concentration of lipid \& 


\section{Article}

lipoprotein, and underlying mechanism where by pregnancy induces hyperlipidaemia have not been fully documented. Therefore, in women with $2^{\text {nd }}$ and $3^{\text {rd }}$ trimester of pregnancy, what changes occur in total cholesterol concentration in our socio economic context? The main objective in this study is to investigate whether the total cholesterol during pregnancy differs from non-pregnant women of similar reproductive life. The rationale of this study is based upon the effect of pregnancy on serum cholesterol metabolism so that steps may be taken to minimize any cardiovascular and other complications, which may help to promote and preserve women's reproductive health. However, attempt is made to asses and evaluates which type of change occurs in the cholesterol metabolism during pregnancy. In this preliminary report, we present the result of total cholesterol measurements perform on 100 healthy women in $2^{\text {nd }}$ and $3^{\text {rd }}$ trimester of pregnancy and compare these with those of non-pregnant women of similar age.

\section{Methods}

A cross sectional study was carried out in the Department of Physiology, Mymensingh Medical College, Mymensingh, Bangladesh during the period of July 2006 to June 2007. A total number of 100 cases of 2 nd and $3^{\text {rd }}$ trimester of pregnancy were participated as study group. This group again subdivided into group 1(A) and 1(B). 1A consist of 50 cases of $2^{\text {nd }}$ trimester of pregnancy and gestational period were 12-28 weeks. 1B consist of 50 cases of $3^{\text {rd }}$ trimester of pregnancy and gestational period were 29-40 weeks. Hundred cases of non-pregnant women matched on reproductive age were considered as control group. Participants those who were suffering from Diabetes mellitus (random blood sugar $>11$ $\mathrm{mmol} / \mathrm{L})^{8}$, Hypertension (blood pressure $>140 /$ $90 \mathrm{~mm}$ of $\mathrm{Hg})^{9}$, Obesity $\left(\text { BMI }>30 \mathrm{Kg} / \mathrm{m}^{2}\right)^{1}$, contraceptive user in control group were excluded from this study. We also exclude $1^{\text {st }}$ trimester of pregnancy because there is no significance change in concentration of serum lipid and lipoprotein between study and control group ${ }^{10,11}$. The sampling technique was convenience type. During visit the available pregnant women and controls those who were present were interviewed and examined. Under strict aseptic precaution, venous blood sample was collected from all subjects Biochemical analysis of serum was carried out for estimation of total cholesterol by CHOD-POD enzymatic method using lipid profile kit, Spinreact SA ctra. Santa Coloma , 7-E-17176 sant Esteve De Bas (Goriona) Spain ${ }^{12}$. Statistical analysis was calculated by SPSS program using unpaired student $t$ test between two groups.

\section{Results}

The 100 subjects with $2^{\text {nd }}$ and $3^{\text {rd }}$ trimester of pregnancy and 100 control matched on reproductive age were participated. Data were expressed as mean $( \pm \mathrm{SE})$ in tables. All the results were expressed in $\mathrm{mmol} / \mathrm{L}$. Table I shows the concentration of total cholesterol in group I (pregnant) and in group II (control), was 5.898( \pm 0.013$)$ vs. $4.276( \pm 0.038), \mathrm{P}<0.001$. The pregnant women had significantly higher concentration of total cholesterol than control.

Table I: Comparative analysis of serum total cholesterol in group I (pregnant) and group II (control) by SPSS

\begin{tabular}{lcccc}
\hline Parameters & Groups & $\begin{array}{c}\text { Mean } \\
\pm \text { SEM }\end{array}$ & t value & p value \\
\hline $\begin{array}{l}\text { Serum total } \\
\text { cholesterol } \\
(\mathrm{mmol} / \mathrm{L})\end{array}$ & $\mathrm{I}=99$ & $\begin{array}{c}5.898 \\
\pm 0.103\end{array}$ & & \\
& & & 14.747 & $<0.001$ \\
& $\mathrm{II}$ & 4.276 & & \\
& $\mathrm{n}=100$ & \pm 0.038 & & \\
\hline
\end{tabular}

$\mathrm{n}=$ number of subjects, SEM = standard error of mean, $\mathrm{p}<0.001=$ highly significant

Table II shows the relative analysis of serum total cholesterol in group $1 \mathrm{~A}\left(2^{\text {nd }}\right.$ trimester $)$ and group II (control). The mean (SE) serum total cholesterol was significantly higher in pregnant than in control.

J Bangladesh Soc Physiol. 2006 Dec;(1):1-4. 


\section{Article}

Table II: Relative analysis of serum total cholesterol in group IA ( $2^{\text {nd }}$ trimester $)$ and group II (control) by SPSS

\begin{tabular}{lcccc}
\hline Parameters & Groups & $\begin{array}{c}\text { Mean } \pm \\
\text { SEM }\end{array}$ & t value & $\mathrm{p}$ value \\
\hline Serum total & 1A & 5.373 & & \\
cholesterol & $\mathrm{n}=50$ & \pm 0.131 & & \\
$(\mathrm{mmol} / \mathrm{L})$ & & & 7.985 & $<0.001$ \\
& II & 4.276 & & \\
& $\mathrm{n}=100$ & \pm 0.038 & & \\
\hline
\end{tabular}

$\mathrm{n}=$ number of subjects, SEM = standard error of mean, $\mathrm{p}<0.001=$ highly significant

Table-III shows the proportional analysis of serum total cholesterol, in group $1 \mathrm{~B}$ ( $3^{\text {rd }}$ trimester) and group II control. The mean total cholesterol concentration was significantly higher in pregnant women of $3^{\text {rd }}$ trimester than in control $(\mathrm{p}<0.001)$.

Table III: Proportional analysis of serum total cholesterol in group IB ( $3^{\text {rd }}$ trimester $)$ and group II (control) by SPSS

\begin{tabular}{|c|c|c|c|c|}
\hline Parameters & Groups & $\begin{array}{c}\text { Mean } \pm \\
\text { SEM }\end{array}$ & t value & $\bar{p}$ value \\
\hline Serum total & $1 \mathrm{~B}$ & 6.434 & & \\
\hline cholesterol & $n=49$ & \pm 0.117 & 17.427 & $<0.001$ \\
\hline$(\mathrm{mmol} / \mathrm{L})$ & $\begin{array}{c}\text { II } \\
\mathrm{n}=100\end{array}$ & $\begin{array}{c}4.276 \pm \\
0.038\end{array}$ & & \\
\hline
\end{tabular}

$\mathrm{n}=$ number of subjects, $\mathrm{SEM}=$ standard error of mean, $\mathrm{p}<0.001=$ highly significant

\section{Discussion}

The finding of this study shows that there is progressive increase in concentrations of total cholesterol, during the course of $2^{\text {nd }}$ and $3^{\text {rd }}$ trimester of pregnancy than controls. This study documents total cholesterol shows about, $70 \%$ increase during pregnancy and reaching maximum $50 \%$ at $3^{\text {rd }}$ trimester of pregnancy in comparison to control. In comparison to other study, the majority of similar study was agreed with this results ${ }^{13,15,16,17}$. In this study, it is difficult to explain how pregnancy hormones increased the serum total cholesterol level. The mechanism whereby pregnancy induces hyperlipidaemia has not been fully documented. Estrogen seems to be responsible for most of the alterations in lipoprotein metabolism during pregnancy, but its action are complemented and opposed by the other pregnancy hormones and in late pregnancy by increasing insulin resistance. The role of progesterone in pregnancy associated hyperlipidaemia is questionable. Progesterone has been to shown to oppose the action estrogens on lipoprotein metabolism, leading to increased concentrations of LDL cholesterol and decreased concentrations of HDL cholesterol. Some authors have suggested that the estrogen progesterone ratio, which is low in early and in very late pregnancy, is important in the balance of the alteration in lipoprotein metabolism throughout pregnancy ${ }^{18}$. This study has certain limitations. Firstly, the subjects were not observed longitudinally. Secondly, the pregnant group was highly selected, the subjects being recruited from women presenting for medical checkups. The results may therefore not be representative of the general population. Thirdly, both study and control groups were non-fasting. Based on a research work it can be concluded that higher concentration of total cholesterol is more common in pregnant than control and reaching maximum at $3^{\text {rd }}$ trimester of pregnancy. However, when determining the need for diagnostic evaluation of hyperlipidaemia, we should consider at list two or three measurement of total cholesterol during pregnancy and follow up measurement would be required after delivery.

\section{Author Affiliations}

*1. Dr M Farhad Husain, MBBS, M Phil, Lecturer of Physiology, Mymensingh Medical College, Mymensingh, Bangladesh, Email: drfarhadmmc (a)yahoo.com

2. Professor Shah Abdul Latif, MBBS, M Phil, FACP, FRCP Edin, Professor and Head of Physiology, Mymensingh Medical College, Mymensingh, Bangladesh. E-mail: salatif@bttb.net.bd

3. Dr M Murshed Uddin, MBBS, M Phil, Associate Professor of Physiology, Mymensingh Medical College, Mymensingh, Bangladesh

* for correspondence 


\section{Article}

\section{References}

1. Guyton AC, Hall JE. Text book of medical physiology. $11^{\text {th }}$ ed. Philadelphia: Elsevier; 2006. p. 872,1017,1027-1033.

2. Keele CA, Neil E, Joels N. Samson Wright's Applied Physiology. $13^{\text {th }}$ ed. New York: Oxford; 2000. p. 574582.

3. Nessa A, Latif SA, Uddin M. Effects of low dose oral contraceptives on serum total cholesterol, TAG, HDLC \& LDL-C levels in contraceptives users. Mymensingh Med J. 2004;14(1):26-28.

4. Fernandez JU, Hoyos AM, Carballo AM, Prieto AP, Ruiz AV, Cosano CR, Monila-Font JA. Lipoproteins in pregnant women before and during delivery influence on neonatal haemorheology. J Clin Pathol. 1996;49:120-123.

5. Murchison LE. Hyperlipidaemia. British Medical Journal. 1985;290:535-538.

6. Koukkou E, Watts GF, Mazurkiewicz J, Lowy C. Ethnic differences in lipid and lipoprotein metabolism in pregnant women of African and Caucasian origin. $\mathrm{J}$ Clin Pathol. 1994;47:1105-1107.

7. Sarker D. Studies on serum total cholesterol, triglyceride, HDL-cholesterol, LDL-cholesterol, creatinine \& creatinine clearance values in hypertensive patients (Thesis). Mymensingh: University of Dhaka; 2006:4-5.

8. Haslett C, Chilvers ER, Boon NA, Colledge NR. Davidson's principles and practice of medicine. $19^{\text {th }}$ ed. Edinburgh: Churchill Livingstone; 2002. p. 649.

9. Sarkar D, Latif SA, Uddin MM, Aich J, Sutradhar SR, Ferdousi S, Ganguly KC, Wahed F. Studies on Serum Lipid Profile in Hypertensive Patient. Mymensingh Med J. 2007 Jan;16(1):70-76.

10. Alvarez JJ, Montelongo A, Iglesias A, Lasuncion MA, Herrera E. Longitudinal study on lipoprotein profile, high density lipoprotein subclass and post heparin lipases during gestation in women. J Lipid Res.1996;37:299-308.

11. Sattar N, Greer IA, Louden J, Lindsay G, Mcconnell $\mathrm{M}$, Chepherd J et al. Lipoprotein sub fraction changes in normal pregnancy: threshold effect of plasma triglyceride on appearance of small, dense low density lipoprotein. J Clin Endocrinol Metab. 1997;82:24832491. Available from: www.jcem.endojounals.org

12. Spinreact, SA. Ctra. Santa Coloma, 7 E-17176 Sant Esteve De Bas (GI) Spain.

13. Saarelainen H, Laitinen T, Raitakari OT, Juonala M, Heirskanen N, Laitine TL et al. Pregnancy-related hypelipidemia and endothelial function in healthy women. Circ J. 2006;70:768-772.

14. Sattar N, Greer IA, Louden J, Lindsay G, Mcconnell $\mathrm{M}$, Chepherd J et al. Lipoprotein sub fraction changes in normal pregnancy: threshold effect of plasma triglyceride on appearance of small, dense low density lipoprotein. J Clin Endocrinol Metab. 1997;82:24832491. Available from: www.jcem.endojounals.org

15. Winkler K, Wetzka B, Hoffman MM, Friedrich I, Kinner M, Baumstark MW et al. Low density lipoprotein (LDL) sub fractions during pregnancy: Accumulation of buoyant LDL with advancing gestation. J Clin Endocrinol Metab. 2000;85:45434550. Available from: www.jcem.endojounals.org

16. Sttar NA, Lindsay G, Greer IA, Packard CJ, Shepherd J. The hyperlipidaemia of normal pregnancy. Atherosclerosis, Supplement. 64, 1995:17. Available from: http://www.ingentaconnect.com/content/els/ 00219150/1995/00000115/90000064/art96321.

17. Potter JM, Nestel PJ. The hyperlipidemia of pregnancy in normal and complicated pregnancies. Am J Obstet Gynecol. 1979 Jan 15;133(2):165-70. Available from: h t t p : / / w w w n c bi.n $1 \mathrm{~m}$.gov/entrez/ query.fcgi?it $001=$ abstractplus $\& d b=$ pubmed $\& \mathrm{cmd}=$ Ret

18. Masurkiewiez JC, Watts GF, Warburton FG, Slavin BM, Lowy C, Koukkou E. Serum lipid, lipoproteins and apoliproteins in pregnant non-diabetic patients. J Clin Pathol. 1994;47:728-731.

19. Young DS. Implementation of SI units for clinical laboratory data. Ann Intern Med. 1987;106:114; JAMA instructions for Authors, JAMA. 1997;278:74.

J Bangladesh Soc Physiol. 2006 Dec;(1):1-4. 